\title{
Giuseppe Veltri \\ Apologetic, Empiricism, and Sceptical Strategies in Simone Luzzatto
}

\section{Introduction}

Simone Luzzatto (?1583-1663) ${ }^{1}$ is the first Jew of the early modern period who, imbued with political philosophical ideas and a sceptical attitude, presented a new empirical concept of Judaism as an integral part of society while also remaining a sceptic intellectual who critically engaged modern sciences and philosophy. He is philosophically in step with the work of the rabbi, preacher, and philosopher Judah Moscato (c. 1533-1590), who asserted the near perfection of mathematics against the weakness of the (new) sciences. ${ }^{2}$

For the first time in the history of Jewish philosophy, a scholar proclaimed himself a sceptic following the New Academy. Already in his first rather apologetic-political work, the Discorso circa il stato degli Hebrei (1638), Luzzatto qualifies himself as new academician:

Political matters are full of alterations and contingencies, and in this Discorso I promised I would follow the probable and the verisimilar, ${ }^{3}$ just as a new academician would, and in so doing [the academician] differs from the mathematicians that are used to following the absolutely verifiable and undeniable. ${ }^{4}$

This article is a chapter I published in my recent book Alienated Wisdom. Enquiry into Jewish Philosophy and Scepticism (Boston and Berlin: De Gruyter, 2018), 213-232, here reprinted for the Yearbook.

1 For a bibliography of and on Luzzatto, see Simone Luzzatto, Scritti politici e filosofici di un ebreo scettico nella Venezia del Seicento, eds. Giuseppe Veltri in cooperation with Anna Lissa and Paola Ferruta (Milan: Bompiani, 2013), 465-499. In this volume the Discorso as well as the Socrate are edited; all quotations of the original text are from this edition.

2 This was also a topic of the Italian academies, in which the study of science and mathematics together with the liberal arts was both common and appreciated; see Michele Battagia, Delle accademie Veneziane dissertazione storica (Venice: Orlandelli, 1826), 35.

3 For a discussion on the term $\pi \iota \theta \alpha v o ́ \varsigma$ as 'verisimilar', see Pierre Gassendi in Sintagma (1658) I, De logicae fine, 5, Opera 1, 79b; cf. Robert Pasnau, After Certainty: A History of Our Epistemic Ideals and Illusions (Oxford: Oxford University Press, 2017); on the second volume of the Exercitationes paradoxicae adversus Aristoteleos II, VI,6 (1659), cf. Delphine Bellis, “Nos in Diem Vivimus: Gassendi's Probabilism and Academic Philosophy from Day to Day," in Academic Scepticism in the Development of Early Modern Philosophy, eds. Plinio Junqueira Smith and Sébastien Charles (New York: Springer, 2016): 125-152; on probable and verisimilar, see ibidem, 130-131.

4 Luzzatto, Discorso, 30r.

Ә OpenAccess. (c) 2018 Giuseppe Veltri, published by De Gruyter. (c))BY-NC-ND This work is licensed under the Creative Commons Attribution-NonCommercial-NoDerivatives 4.0 License. 
Being a mathematician, as we can infer at least from some parts of his Socrate (1651), ${ }^{5}$ Luzzatto was acquainted with axiomatic systems, demonstrably consistent because of their absence of contradiction per definitionem. He was, however, of the opinion that axiomatic logic does not work in the consideration of human affairs and political matters, and that the philosopher cannot reach a judgment on them with the sole help of probable and verisimilar argumentations because contradiction is here more often the rule than the exception. The adoption of the categories of plausibility and verisimilitude occurred first in the Discorso, the first field of his sceptical training, while in Socrate he presents very detailed strategies against dogmatic thought in almost every branch of human science and wisdom. To my knowledge, Socrate is the first extant treatise on scepticism written by a Jew.

The main emphasis here will be, therefore, to evince some subtle sceptical strategies Luzzatto used to substantiate the (right of) existence of the Jews despite and because of their differences in the face of the Venetian society and government; he weakened the arguments against Judaism and the Jews that were generated by their detractors and enemies.

Although the Discorso and Socrate do have very different literary structures and therefore belong to different genres and address two different types of audience, it is my conviction that both of them follow the same sceptic logic: to counter dogmatic ideas and preconceptions with the intent to create at least an equipollence of arguments and culminate politically with the pragmatic issue of how to integrate the Jews into Venetian society. In the Discorso, Luzzatto defends the integral role of the Jews in the Venetian society against the alleged reason of political and religious incompatibilities between them and Christianity. In his philosophical work Socrate, he is in favour of the suspension of judgment for Socrates because of the impossibility of an impartial process and correspondent plausible judgment. In the first case, we have empiricism against dogmatism, in the second we observe the necessity of the epoché; all of them are sceptical strategies. In this essay, I will deal primarily with the Discorso.

\section{Apology and Apologetic}

According to some scholars, Luzzatto's Discorso falls into the category of the apology or 'modern' apologetics of Judaism in Venice. ${ }^{6}$ Because of my special research interest focussed on sceptical strategies, it is worthwhile to explain some concepts surrounding the field of apology/apologia in modern (English) language.

5 Cf. Luzzatto, Socrate, 68.

6 Cf. Francesca Trivellato, “Jews and Early Modern Economy,” in The Cambridge History of Judaism, vol. 7: The Early Modern World, 1500 -1815, eds. Jonathan Karp and Adam Sutcliffe (Cambridge: Cambridge University Press, 2018): 161. 
The terms apology, apologia, and apologetics seem to philologically include the same concept, but philology does not play the decisive role here. Today the English word apology means 'the act of declaring one's regret, remorse, or sorrow for having insulted, failed, injured, harmed or wronged another. ${ }^{7}$ Yet, apologia derives from the

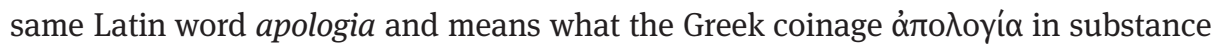
addresses: 'verbal defence, speech in defence.' The first literary and philosophical occurrence known to me is the Apologia of Socrates.

By contrast, apologetics is systematic argumentative discourse in defence of a doctrine/ religion, as every dictionary confirms. ${ }^{8}$ The method of the defence of apologetics may be similar to apologia but the goal is very different. Apologetics may and could have a missionary objective to convert people to the 'true' religion, the 'right' doctrine, while an apologia is primarily a defence designed to convince the judge of one's innocence in opposition to a prosecutor's arguments. The goal is to reach at least an equipollence of arguments. At any rate, an apologia is by no means an apology; it is not a remorseful speech or a term acknowledging wrongful or offensive action and it must also be properly located in the realm of jurisprudence and in philosophical/rhetoric dialectic discussions.

Further, it is well-known that in an accusatorial process the task of the defendant is to try to abate every charge of the accusation by using an arsenal of rhetorical tools, adducing evidence, (accurate) testimony, and (alleged or consistent) proof: all strategies in order to undermine the claim and argument of the (state) prosecutor. I will come back to this point later in my discussion of rhetorical logic and the results of a rabbinic discussion. At this point, I would like to confine myself only to written apologias by emphasising that writings in defence of individual or (political, religious, ethnic) groups against the charges of the majority or the ruling powers, are called 'apologia' because they are defending their own point of view, behaviour, or identity which are different from that of the majority. The strategies involved in apologia and apologetics are similar: to produce evidence to counter the adversary, to reduce an accusation to a self-contradiction, and to disavow the charges, removing all legitimacy and plausibility from the construction of the prosecutor's indictment.

Luzzatto adopts this strategy for dismantling the accusation that the Jews are unsuitable to Christian society due to their identity as a different ethnic group and religion. He does not repeat ancient and traditional arguments of antiquity and (messianic) legitimacy in favour of the Jews, but he refers to the experiential, empirical argument of the socially cohesive nature and economic usefulness of the Jews of Venice. It is of course well known that empiricism and scepticism are not the same philosophical movement; however, they use very similar strategies and base their arguments on pragmatic facts based on experience.

7 Quoted from Mihaela Mihai, “Apology,” in Internet Encyclopedia of Philosophy, http://www.iep.utm.edu/apology/ (accessed 3 May, 2018).

8 See, for example, https://www.britannica.com/topic/apologetics (accessed 3 May, 2018). 
A few words and notations should be addressed towards the topic of experience as a philosophoumenon both of the empiricism and scepticism. ${ }^{9}$ The question of similarity between the two Greek schools is very old and goes back to Sextus Empiricus. Nevertheless, there is more. The discussion of whether Sextus, author of the main fonts of ancient scepticism, was an empiricist or not, as some ancient sources suggest, ${ }^{10}$ does not obscure the fact that ancient empiricism did not admit a dogmatic vision of healing in its methods. Sextus recognises some validity to their strategies, when he affirms:

Some say that the Sceptical philosophy is the same as the Empiric school in medicine. But you must realize that if this form of Empiricism makes affirmations about the inapprehensibility of unclear matters, then it is not the same as Scepticism, nor would it be appropriate for Sceptics to take up with that school. ${ }^{11}$

Although he seems to counter medical empiricism, he does seem to accept the medical method:

They might rather adopt, as it seems to me, what is called the Method; for this alone of the medical schools seems to practise no rashness in unclear matters and [the empiricist school] does not presume to say whether they are apprehensible or inapprehensible, but it follows what is apparent, taking thence, in line with Sceptical practice, what seems to be expedient. ${ }^{12}$

Independent from the question of the goals and of the approach to medicine, Sextus cannot negate the fact that empiricism and scepticism adopt very similar tactics. ${ }^{13}$ Both of them back their strategies with experience ( $\left.\dot{\varepsilon} \mu \pi \varepsilon \rho^{\prime} \alpha\right)$, a medical attitude of general significance, as an example of linguistic scepticism. To abate the grammarian's dogmatic vision of the 'natural significance' of words, he bases his criticism on the experience with the 'Barbarians' and comments:

If nouns exist 'by nature' and are not significant in each instance by reason of convention, then all men ought to understand the speech of all, Greeks that of barbarians and barbarians that of

9 Cf. Emidio Spinelli, "L'esperienza scettica: Sesto Empirico fra metodologia scientifica e scelte etiche," Quaestio 4 (2004): 25- 43.

10 Cf. Alan Bailey, Sextus Empiricus and Pyrrhonean Scepticism (Oxford: Oxford University Press, 2002), 93-99; cf. Roderick M. Chisholm, "Sextus Empiricus and Modern Empiricism," Philosophy of Science 8.3 (1941): 371-384.

11 Sextus Empiricus, Outlines of Pyrrhonism I:236; all English translations are taken from Sextus Empiricus, Outlines of Scepticism, eds. Julia Annas and Jonathan Barnes (Cambridge: Cambridge University Press, 2000).

12 Sextus Empiricus, Outlines of Pyrrhonism I:236-237.

13 It is not my intent here to deal with every aspect this topic involves. I refer the reader to the detailed study of Emidio Spinelli, "Sextus Empiricus," in Dictionnaire des philosophes antiques, ed. Richard Goulet (Paris: CNRS éditions, 2016): 265-300; on empiricism, see ibidem, 279-282. 
Greeks and barbarians that of (other) barbarians. But this is not the case; therefore, nouns are not 'naturally' significant. ${ }^{14}$

The argument used here is from experience (that of the Barbarians and the Greeks), not from the realm of logic or metaphysics. Also well-known is his argument about the moral(s) of society: every people have different moral standards, ergo there is not a common morality 'by nature.' Furthermore, the argumentation 'by nature' can be but treacherous for the dogmatic because of the experience of good and bad, or according to his words:

For those who hold the opinion that things are good or bad by nature are perpetually troubled. When they lack what they believe to be good, they take themselves to be persecuted by natural evils $\left[\ldots . . .^{15}\right.$

Empiricism as a school and as a medical practice is not confined to ancient philosophy and medicine, it has a long history in the Middle Ages, Renaissance, and early modern period. Beginning with the schools of Roger Bacon and William of Ockham in Middle Ages, its apex occurred in the late Renaissance with Machiavelli and Guicciardini. Yet, from the De rerum natura iuxta propria principia (On the Nature of Things According to their Own Principles) by Bernardino Telesio in 1586 and Michel de Montaigne's "On Experience"16 to Francis Bacon onwards, empiricism experienced new modes of transmission and discussion. Luzzatto's acquaintance with it may derive from his study of Pierre Gassendi, a very probable source of his writing and perhaps a favourite reading. ${ }^{17}$ Additionally, Francis Bacon was one of the sources of Luzzatto's attitude towards the sciences, mostly plausibly his first address for the doctrine of the induction. Francis Bacon is often indirectly quoted in the Discorso, as I have demonstrated elsewhere. ${ }^{18}$

14 Sextus Empiricus, Against the Professors, I:VII, §144-145 (Loeb, 1949, 86-87).

15 Sextus Empiricus, Outlines of Pyrrhonism I:27; see also I:30. Cf. Michael Frede, “The Sceptic’s Beliefs," in The Original Sceptics: A Controversy, eds. Myles Burnyeat and Michael Frede (Indianapolis: Hackett, 1997): 22.

16 Michel de Montaigne, “Of Experience,” ed. Patrick Madden, trans. Charles Cotton (1588; 13 September, 2006). http://essays.quotidiana.org/montaigne/experience/ (accessed 3 May, 2018).

17 Cf. Giuseppe Veltri, “Opere e pensiero di Simone Luzzatto," in Luzzatto, Scritti politici e filosofici: LXXX.

18 Giuseppe Veltri, "Economic and Social Arguments and the Doctrine of the Antiperistasis in Simone Luzzatto's Political Thought: Venetian Reverberations of Francis Bacon's Philosophy,” Frühneuzeit-Info 23 (2011): 23-32. 


\title{
2 Luzzatto's Strategies and the Tropoi of Sextus
}

Concerning the strategies of Luzzatto it is valuable to foreground some observations before we handle them in detail. In the Discorso, the rabbi uses some strategies to abate dogmatic principle (read: main, current, and influential opinions). The reader may be sceptical about my approach in this book on Luzzatto's language of scepticism and relative strategies. While it is true that the tropoi are indirect, they are the basic elements of the Socrate, as Michela Torbidoni has demonstrated, ${ }^{19}$ and, in the Discorso, the Rabbi twice directly quotes Sextus Empiricus, on both occasions from the tropoi, which I would call strategies of scepticism.

In the first quotation, he speaks of moral scepticism, attacking Tacitus's calumny 'to defame the Jewish Nation,' painting it as dissolute in its carnal impulses: 'and although as a race, they are prone to lust, they abstain from intercourse with foreign women; yet among themselves nothing is unlawful. ${ }^{20} \mathrm{He}$ adds: ${ }^{21}$

\begin{abstract}
But if this refers to the customs of the Jews, it could not be further from the truth, since there has never been a nation more restricted regarding carnal relationships than the Jews. The Egyptians, who were by no means barbarians, but in fact passed on many doctrines to the Greeks, took their sisters for wives, and the Ptolemaic kings set an example [of this habit] to the common people. The Persians, who enjoyed dominion over Asia and the subjugation of Greece, passed to a higher level of turpitude, permitting sons to wed their own mothers. Chrysippus, the propagator of Stoic philosophy, claimed that he was responsible for the reform of the human race. And yet he remained indifferent in the face of such a detestable practice; on the contrary, by means of some of his reasoning he sought toss describe it as almost honest, as one can read in the books of Sextus Empiricus. ${ }^{22}$
\end{abstract}

The argumentation is here highly imperative: Luzzatto's defence of Jewish custom neither takes into consideration the (im)morality of an act commanded by the God of the Jews (to refrain from intercourse with foreign women), thereby avoiding a return to the argument of a heteronomous moral act, nor does he found it on morality based on 'nature.' He infers the immorality from the discrepancy with the high esteem in which other peoples in the world community (Egyptian and Greeks) were held despite their incestuous and lascivious customs. With reference to the above listed sexual practices, Luzzatto states that the moral code of the Jews is more restrictive than that of Egyptian and Greeks, although they are judged as 'barbarians' despite their probity. This is not a dogmatic argument, but a strategy taken from experience grounded in moral scepticism and relativism. The Sextian argument against natural

19 Michela Torbidoni, "Il metodo del dubbio nel Socrate," in Filosofo e Rabbino nella Venezia del Seicento. Studi su Simone Luzzatto (ca.1583-1663). Con un'appendice di documenti inediti dall'Archivio di Stato, ed. Giuseppe Veltri (Rome: Aracne, 2015): 183-245.

20 Tacitus, Historiae V:5.

21 Luzzatto, Discorso, 59v-60r.

22 Sextus Empiricus, Outlines of Pyrrhonism I:152 and 160. 
morality was very similar: he quoted several examples of different customs in decisive moral acts like sexuality, which differed among Romans, Greek, Indians etc., an argument rooted in a multifaceted approach to law and custom. ${ }^{23}$ Luzzatto emphasises a particular element: the high esteem in which some cultures were held despite their even more radical difference in morality, e.g. the Egyptians enjoy our elevated cultural esteem despite their flagrant, according to our standards, immorality.

The second direct quotation is more complicated because he, speaking of the phenomenon of the Kabbalah, associates the 10 principles (the Sefirot) and their flux to some ideas of the Platonic system of object and motion. It is not my intention here to analyse the strategies of the anti-kabbalistic essay of Luzzatto, already examinated by Bill Rebiger in the Yearbook of 2017, ${ }^{24}$ but only his ars relationis of the Sefirot, their relation and Plato's world of the ideas. Luzzatto writes:

Plato, however, adhering in part to the said opinion, yet in a calmer manner, was not satisfied with entirely denying the existence and permanence of the being of whatever thing. For he conjectured that beyond the apprehension of our senses there were some firm and fixed substances. [According to his view,] these substances need neither a confrontation nor a relation to others, and thus could have a stable and firm existence in themselves. Furthermore, these [substances] were the origins of those apprehensions that we perceive and could be called shadows and unsubstantial appearances. This is the doctrine he affirms in his Letters, ${ }^{25}$ which involves a great application of mind and a great force of intellect to apprehend a thing as pure, genuine, and bared of the commingling of relation and motion. For every object is burdened and wrapped up in these. This is what Sextus Empiricus demonstrated, i.e. that every phenomenon and object is mixed and involved in five kinds of relations. Proceeding in his examination, he even demonstrated that it is almost impossible to grasp anything about objects other than their relation. This thing [the relation] would be so feeble and slight that the Stoics, and after them the Nominalists, negated its existence, [by saying that] it was chimerical and imaginary, or even better, verbal. ${ }^{26}$

The reference to Sextus in confirming a Platonic view of the system of the ideas and their relationship is tricky because Sextus does negate the existence of all fixed and firm substances. It is enough to refer here to Outlines of Pyrrhonism III:3:

Now, since some of the Dogmatists say that god is a body, others that he is incorporeal, some that he is anthropomorphic, others not, some in space, others not-and of those who say that he is in space, some say that he is within the universe, others that he is outside it-how shall we be able to acquire a conception of god if we possess neither an agreed substance for him nor a form nor a place in which he is?

23 Sextus Empiricus, Outlines of Pyrrhonism, I:152: 'We oppose custom to the others-for example, to law, when we say that in Persia homosexual acts are customary, while in Rome they are forbidden by law.'

24 Bill Rebiger, "Sceptical Strategies in Simone Luzzatto's Presentation of the Kabbalists in his Discorso," in Yearbook of the Maimonides Centre for Advanced Studies 2017, ed. Bill Rebiger (Berlin and Boston: De Gruyter, 2017): 51-69.

25 Luzzatto probably refers to the $7^{\text {th }}$ Epistle of Plato.

26 Luzzatto, Discorso, 81v-82r. 
But that is only one side of the question because Luzzatto connects the theory of the Sefirot to Plato's world of substances. Besides the tradition of this theory, already examined by Moshe Idel, ${ }^{27}$ Luzzatto's strategic aspect cannot be concealed: fixed substances have a firm existence in themselves and therefore cannot be apprehended if not in their shadowy and unsubstantial appearances. According to Luzzatto's rendition of Sextus 'every phenomenon and object is mixed and involved in five kinds of relations.' He concludes 'that it is almost impossible to grasp anything about objects other than their relation.' As Emidio Spinelli wrote to me in an epistolary communication, Luzzatto may be referring here to the sceptic Agrippa. Sextus reported Agrippas' tropoi, ${ }^{28}$ among them that of relativity, in his Outlines of Pyrrhonism. ${ }^{29}$ The confusion has probably resulted, I imagine, because Agrippas' five modes are quoted by Sextus, as mentioned before.

Yet, as Spinelli comments, Sextus also speaks of the relativity in Outlines of Pyrrhonism I:38 - 39 as a hierarchical submission of all tropoi to it. Expressly in Outlines of Pyrrhonism I:140, he affirms:

So, since we have established in this way that everything is relative, it is clear that we shall not be able to say what each existing object is like in its own nature and purely, but only what it appears to be like relative to something. It follows that we must suspend judgement about the nature of objects.

Ancient authors convey that Pyrrhonians were also relativists, ${ }^{30}$ but an assimilation of their thoughts is not without problems, as Annas and Barnes sustain. ${ }^{31}$ The pros $t i$ of relations/relativity is also a topic of Stoic philosophy, as Luzzatto notes, which introduces or sustains the insubstantiality of relation in the cases of verbal definition, as 'father' is father so long as he has a child, as Simplicius, in his Commentary on Aristotle's Categories comments. ${ }^{32}$

27 That is, Isaac Abravanel; cf. Moshe Idel, "Jewish Kabbalah and Platonism," in Neoplatonism and Jewish Thought, ed. Lenn E. Goodman (Albany: State University of New York Press, 1992): 332-333. He speaks of the Sefirot as Platonic ideas and 'separate universal forms.' Yohanan Alemanno also speaks of the Sefirot as the primordial ideas of Plato.

28 Sextus Empiricus, Outlines of Pyrrhonism I:164-177: "The Five Modes."

29 See Emidio Spinelli, Questioni scettiche. Letture introduttive al pirronismo antico (Rome: Lithos, 2005), 32-33.

30 Cf. Julia Annas and Jonathan Barnes, The Modes of Scepticism: Ancient Texts and Modern Interpretations (Cambridge: Cambridge University Press, 1997), 97.

31 Ibidem, 98.

32 Cf. ibidem, 134-135: 'But when it is observed not in virtue of an internal difference but solely in virtue of its relation to something else, it will be a thing somehow in relation to something. Sons and people on the right require certain external things for their subsistence. That is why, even if no change takes place in themselves, a man may cease to be a father when his son dies and someone may cease to be on the right when what was next to him has changed position.' The interpretation of Annas and Barnes does not take into account the oral element of stoic discourse. 
Luzzatto likes to demonstrate that a precise analysis of relations results in the conclusion that we cannot grasp the object of anything. The goal of his sentence is the negation of the dogmatic assertion of the existence of Plato's substances and, in this way, the Sefirot. From given relations we cannot infer a given substance.

It is important here to realise that sceptical strategies are at work in the Discorso, especially because Luzzatto considers himself in step with Sextus' scepticism, although he defines himself a New Academician and, therefore, not a Pyrrhonian. In the following section I will present some sceptical strategies present in Luzzatto's work, all of which are based on experience and achieved in history and society. Nevertheless, I suppose that Luzzatto is also using the tropoi, or strategy, of Sextus and Agrippa, using it as a political tool for describing, defending, and apologising for the Jews of Venice. I will select the political strategies of relation/relativity, recess, and necessity, and end with the argument concerning the 'nude truth.'

\section{The Strategy of Relation/Relativity}

Sextus Empiricus and Agrippa ${ }^{33}$ agree-as I discuss above-that things are together by virtue of their relation and not due their nature. We will return to this idea with reference to usury. Here I would like to stress that the 'relationship' between the elements of society is the backbone of its political structure, as well as the commitment of Luzzatto to the apologia. The presence of the Jews in Venice is due to their integration into every part of its fabric and life. Integration is not the deprivation of their factuality as Jews (i.e. conversion) but the recognition of their very clear position in society. This participation is not substantial but relative to the 'state of the Jews in Venice.' But first something on the Discorso.

Luzzatto's political thesis in the first part of the Discorso is simple and, at the same time, temerarious: Venice can put an end to its political decline, he argues, by offering to the Jews a monopoly on overseas commercial activity. This proposal recommends itself because the Jews are 'well suited for trade,' far more so than others (such as 'foreigners'). The Rabbi opens his argument by recalling that trade and usury are the only occupations permitted to Jews. Within the confines of their historical situation, the Venetian Jews became particularly adept at trade with partners from the Orient. This talent could be put to the use by the Venetian government for maintaining-or, more accurately-recovering its political importance as an intermediary between the East and the West. Luzzatto was the first to define the role of the Jews on the basis of their economic and social functions, disregarding the classic categorisation of Judaism's (privileged?) religious status in world history.

33 A Pyrrhonian philosopher probably of the first century BCE and author of five tropoi, reported by Sextus, Outlines of Pyrrhonism I:164-169. 
Luzzatto prefaces his treatise with an "Introduction," ${ }^{34}$ ostensibly intended to provide a theoretical outline of the political and economic aspects of his subject, a reflection also of his vision of the customs and ways of life followed by the Jews of the Diaspora. In this introduction to the 'whole' tractate, he deals, in fact, with only one issue: the status of the Jews of Venice and their economic situation, which is, in turn, the topic to which the entire first part of the Discorso is devoted. Luzzatto clearly states his central thesis right from the outset: the ancient people of the Jews, present today in the illustrious city of Venice, are, in their constitution and way of life, a 'fragment' of the God's original creation. ${ }^{35}$ Nobody, he claims, can contest the proposition that Venetian Jews are a 'reward' (emolumento) to the city of Venice and that they constitute an integral part of the common populace. ${ }^{36}$

The Rabbi of the Ghetto of Venice avails himself of the fragment metaphor: the Jewish community of Venice is as a Democritian atom in the Milky Way of the Venetian res publica. ${ }^{37}$ Although the Rabbi has serious doubts as to the cosmological value of Democritus' philosophy, he seems to accept its usefulness as a source of metaphor:

And if this opinion was rightly condemned, what occurred to those men was more a result of the casual coupling of small bodies, which those philosophers proposed, rather than a result of the absurdity of the construction. ${ }^{38}$

The purpose of his treatise is not primarily to celebrate the antiquity of the Jews but rather to present some of the advantages they bring to the State. He considers the Jewish people as an integral part of city of Venice or, better, of the entire world. The function of the Jews, he claims, is similar to that of the atoms of Democritus that populate the 'Lower World,' which, in turn, feeds with its vapour the sun, the moon, and the other stars: a stoic idea. In this sense, every kingdom on the earth is comparable to the galaxy. ${ }^{39}$

The metaphors he uses to describe the composition of society serve to draw attention to two specific points: that every element of society, and in particular that of

34 Luzzatto, Discorso, $7 \mathrm{r}-8 \mathrm{r}$.

35 Ibidem, 6v: 'because the common consensus among men agrees that there was a time when this People took their form of government and social institutions from the Highest Artist.'

36 Ibidem, $7 \mathrm{v}$.

37 Ibidem, $7 \mathrm{r}$.

38 Ibidem. Luzzatto seems here to refer to a criticism of atomistic theory, which was introduced into European intellectual circles by Gassendi. Luzzatto himself was a follower of sceptical theory. On Gassendi and scepticism, see Richard H. Popkin, The History of Skepticism from Erasmus to Spinoza (Berkeley: University of California Press, 1979).

39 Cf. Francis Bacon, Essays XIX: Of Empire: 'Princes are like to heavenly bodies, which cause good or evil times; and which have much veneration, but no rest. All precepts concerning kings, are in effect comprehended in those two remembrances: memento quod es homo; and memento quod es Deus, or vice Dei; the one bridleth their power, and the other their will.' On the classical origin of the idea, see A. I. Ellis, "Some Notes," The Classical Review 23 (1909): 246-247. 
Venice, should be fully integrated as a prerequisite to their contribution to the welfare of the whole. That is also the logic of the human body as Luzzatto expressly indicates, citing indirectly the fable of Menenius Agrippa: ${ }^{40}$

[...] So too when our stomach suffers from lack of food, it lives on suitable humours with great pain and distress of other limbs..$^{41}$ But when the opposite occurs, and there is an abundance of nourishment, there is respite from the plundering, and this relief spreads to other parts of the body. Similarly, the preponderance of duties and passage taxes not only frees the populace from the burden of taxes and contributions-which they would be obliged to pay in emergencies and for the needs of the Prince-but also itself profits of this abundance of public money with not little advantage. ${ }^{42}$

In sixteenth century, the metaphor of the stomach becomes more specific: in 1612 Francis Bacon writes in his Of Empire 11:

For their merchants, they are vena porta; and if they flourish not, a kingdom may have good limbs, but will have empty veins, and nourish little. Taxes and imposts upon them, do seldom good to the king's revenue; for that that wins in the hundred, he leeseth in the shire; the particular rates being increased, but the total bulk of trading, rather decreased. ${ }^{43}$

Luzzatto substantially agrees with Bacon. Taxes on imports and exports are lethal for an economy because they lead to a decrease in trade volume. In the end, the state treasury will end up with little more than usual. In addition, there is a moral aspect that should be also taken into consideration: the state should avoid imitating the ancient Romans who 'ultimately imposed taxes on human excrement [...] and even disgraceful and obscene operations such as these helped enrich the treasury. ${ }^{44}$ In contrast to this depravity on the part of the ruling power, the Republic of Venice 'has the custom of imposing taxes only on the industry of men, and not on their lives; to punish their vices, and not to profit from them. ${ }^{45}$ We have here, then, the principal ingredients of Luzzatto's political theory: 1) the Jews of Venice are an integral part of the Republic; 2) their function in commerce is vital and can be of true benefit only if the taxes imposed remain limited, since the taxes on imports and exports have a lethal effect on the general economy; 3) the Republic of Venice was founded on pragmatic ideas.

40 Livius, Ad urbe condita, II 32.

41 Galen thought that blood was produced in the liver from the food the stomach transported there via the portal vein. On the state of medicine at this time, based largely Galen, see Rudolph E. Siegel, Galen's System of Physiology and Medicine: An Analysis of his Doctrines and Observations on Bloodflow, Respiration, Humors and Internal Diseases (Urbana: University of Illinois Press, 1993).

42 Luzzatto, Discorso, 7v.

43 The Works of Francis Bacon, vol. 6, eds. James Spedding et alii (London: Longman and co., 18571874; reprint 2011), 422.

44 Luzzatto, Discorso, 8r.

45 Ibidem. 
We can add that Luzzatto-if using the sceptic topos of relativity-argues that the relation of the Jews to the Serenissima is a profitable one and that changes to this relation (i.e. their expulsion from Venice) would also change the 'state' of the Jews in Venice, and perhaps also Venice itself.

Another application of the political strategy of relation/relativity can be found in chapter 12 of the Discorso in which Luzzatto addresses the criticism of the Jewish presence as voiced by three different groups: religious zealots, politicians and statesmen, and the common people. The religious zealots claim that toleration of a religion that differs from the official faith is contemptuous; politicians argue that there is no utility to tolerating a diversity of religions in the same city, both because of the possibility of sacrilege and because of bad example that one group may provide to the remainder of the population; and the common people simply believe and repeat any calumny and false slander invented out of hatred for the Jewish nation.

In response to the religious zealots, Luzzatto notes that the Pope himself admitted Jews into the city of his own residence, and that they have been living there for over 800 years. To the politicians he offers a very detailed response, stressing the physical separation between Jews and Christians, which is reinforced by Jewish law, according to which ritual contact and sexual relations with non-Jews are prohibited, as is proselytism. As for the crime of usury practiced by the Jews-he adds that it is only tolerated by their laws rather than expressly permitted, referring indirectly to Francis Bacon.

As for the denunciations of the common people, Luzzatto responds:

Truth alone is harsh, and not very pleasing, whereas falsity is admired and delightful. The former is subjected to the occurrence of events; the latter free and wandering. The former is produced by the action of the object that impressed it in our mind, while the latter depends upon human judgments, and like our offspring, one brings them loving affection. ${ }^{46}$

He then deals more specifically with the calumny of the Jews having been unfaithful, and with their purported friendship with pirates. Contrary to what his opponents maintain, Luzzatto describes the Jews as a harmonious part of society, living in reciprocal sympathy with their neighbours in keeping with the will of God, who 'decreed that all humanity should conform together in unanimous amity, each man considering himself a citizen of one commonwealth. ${ }^{47}$ Religious differences, as he points out in chapter 14 and as we have analysed in the second part of my book Alienated Wisdom, are by no means a good reason for war. ${ }^{48}$

The perspicacious reader recognises here a typical strategy of referring to the successful integration of Jews into the Venetian city and their utility under the sky

46 Ibidem, 44r.

47 Ibidem.

48 Ibidem, 51v. Cf. Isaac Abravanel, Perush al nevi'im aaronim (Tel Aviv, n.d.): 9; and Johann Maier, Kriegsrecht und Friedensordnung in jüdischer Tradition (Stuttgart: Kohlhammer, 2000), 403. 
of the Serenissima. The reason given is not a dogmatic reference to the Revelation on Sinai, but rather the activity of the Jews, originating in historical necessity. Their success is dependent on the conservation of their status as Jews as well as their utility for Venice; ${ }^{49}$ that is, the key for the Jews' integration into Venetian society is to fill and to continue to fulfil the social position they already hold, a kind of political recess ad infinitum.

\section{Strategy of Necessity, or, How to Explain recess ad infinitum Politically}

Luzzatto uses a typical political-economic category, 'necessity'. Necessitas as a category must not be confused with the Aristotelian logical concept of necessitas, ${ }^{50}$ and it also occurs in sceptical philosophy: necessity is the reason, according to the sceptical philosophy of Sextus, to suspend every judgment. ${ }^{51}$ The context of Sextus' use is totally different, but Luzzatto's logical use of necessity is very similar: to search for the major cause of necessity would regress to an analysis of animals, which do not possess reason. Luzzatto indirectly refers to regress to the causes of the situation of the Jews, because necessity is the situation into which humans are born and to which man can positively react, or, according to Luzzatto's wording:

The majority of men claim that nature has thrust upon them and vexed them with obligations and necessities in greater abundance than other animals which are deprived of reason. But these men [the majority] complain of duty, because poverty and need are the true stimuli and incentives that result in the inventions and discoveries of the most worthy and excellent arts, which so ennoble the human race. ${ }^{52}$

The proverb mater artium necessitas, 'necessity is the mother of invention,' has a long tradition. In the Middle Ages, it was an operative concept of the political tradition, used in conjunction with other political terms such as virtus and fortuna. ${ }^{53}$ There is of course a common use of the proverb which probably first appeared in print in 1519 in the Vulgaria of William Horman, 'a book of aphorisms for the boys

49 On both categories during the Renaissance, see Paul-Erik Korvela, The Machiavellian Reformation: An Essay in Political Theory (PhD dissertation, University of Jyvaskyla, 2016), 119-120.

50 Lambert Marie de Rijk, Aristotle: Semantics and Ontology. Philosophia Antiqua, vol. 91, no. 1 (Leiden: Brill, 2002), 569; Nathanael Stein, “Causal Necessity in Aristotle,” British Journal for the History of Philosophy 20 (2012): 855-879.

51 For Outlines of Pyrrhonism I:175-176, see Casey Perin, The Demands of Reason: An Essay on Pyrrhonian Scepticism (Oxford: Oxford University Press, 2010).

52 Luzzatto, Discorso, 18r.

53 On the triad, cf. Felix Gilbert's chapter "Fortune, Necessity, and Virtù" in idem, Machiavelli and Guicciardini: Politics and History in Sixteenth-Century Florence (Princeton: Princeton University Press, 1965): 191-200. 
of the schools to learn by heart. ${ }^{54}$ Yet numerous individuals and intellectuals were acquainted with this proverb and its inherent political-philosophical meaning. One such person was Leonardo da Vinci. ${ }^{55}$ The category of necessity, however, did not become a political category with clear-cut criteria until Machiavelli's opus, ${ }^{56}$ to which Luzzatto most likely refers.

According to the Rabbi of Venice and in agreement with the generally accepted history of the Jews since the Middle Ages, trade and money-lending were the only occupations permitted to the Jews. This historical necessity engendered in the Venetian Jews a highly developed capacity for these occupations. Consequently, they were considered by Luzzatto potentially capable of assisting the Venetian government in maintaining, or, to be historically more accurate, recovering, a position of political equilibrium between the East and the West. To put this briefly with respect to a very intriguing aspect of the political life of the Jews in Venice: the Discorso was published in 1638 in a period in which the political power of Venice was beginning to wane. His philosophical work Socrate, published in 1651, expressly refers to the Turkish threat against Crete and to the war in which Venice was involved. Hence, Luzzatto tried to offer the Governor of the Serenissima a political-economic prescription to restore the vital trade of Venice by offering the Jews more economic and social freedom.

Bacon's conviction was that 'It is against nature for money to beget money, ${ }^{, 57}$ echoing an Aristotelian-Thomistic conviction. ${ }^{58}$ However, that is only a superficial read of Bacon's analysis, vision, and inferences.

54 It is very difficult to locate the origin of the proverb. Recent works refer it to Curtius Rufus's Historia Alexandri Magni, 4,3,24: 'Efficacior omni arte imminens necessitas;' see Hubertus Kudla, ed., Lexikon der lateinischen Zitate. 3500 Originale mit Übersetzungen und Belegstellen, 3rd edition (Munich: Beck, 2007), n. 1439. I think that there is no precise Latin quote, but for a Latin sapiential tradition of it, see all the proverbs on 'necessity' quoted by the Hoyt's New Cyclopedia of Practical Quotations (New York: Funk \& Wagnalls, 1922), 559; see also the collection of examples of this phrase at http://www.phrases.org.uk./meanings/necessity-is-the-mother-of-invention.html (accessed 3 May, 2018).

55 Cf. Scritti letterari di Leonardo da Vinci, ed. Augusto Marinoni (Milan: Rizzoli, 1974), 7: 'La necessità è tema e inventrice della natura, e freno e regola eterna.' See the very interesting philosophical evaluation of the maxim in Herr von Prantl, "Leonardo da Vinci in philosophischer Beziehung," Sitzungsberichte der königlichen bayerischen Akademie der Wissenschaften zu München. Philosophischphilologische Classe. Jahrgang 1885 (Munich: Akademische Buchdruckerei, 1886), 17.

56 On the use of 'necessitas' in Machiavelli, see Machiavellism: The Doctrine of Raison D'Aetat and Its Place in Modern History, trans. Douglas Scott (New Haven: Yale University Press, 1957).

57 Francis Bacon, "Of Usury," in idem, Essays (1625); see William Shakespeare, The Merchant of Venice, I, 3: 'Antonio. Or is your gold and silver Eues and Rams? Shylock. I cannot tell, I make it breede as fast.' See Francis Bacon, The Essays or Counsels, Civil and Moral, ed. Brian Vickers (Oxford: Oxford University Press, 1999), 94.

58 Thomas Aquinas, Summa Theologica, trans. Fathers of the English Dominican Province (London: R. T. Washburne, Ltd., 1918), 330 -340, reprinted in Roy C. Cave and Herbert H. Coulson, A Source Book for Medieval Economic History (Milwaukee: The Bruce Publishing Co., 1936; reprinted, New 
An in-depth study of Bacon's conception of usury reveals a more complex attitude which, as we shall see, is similar to that of the Rabbi of Venice. Bacon is adamant in his opposition to usury, and it should be borne in mind that this activity as perceived by Luzzatto and Bacon was not only the act or practice of lending money at an exorbitant rate of interest, but rather simply the practice of lending money at any rate of interest at all. ${ }^{59}$ However, the Lord of Verulam was well aware of the advantages of such activities. In his "Essay on Usury," he enumerated the advantages and disadvantages of usury, including the danger of capitalisation:

The fourth [disadvantage of usury is], that it bringeth the treasure of a realm, or state, into a few hands. For the usurer being at certainties, and others at uncertainties, at the end of the game, most of the money will be in the box; and ever a state flourisheth, when wealth is more equally spread. $^{60}$

Luzzatto also refers to an ideal situation of greater equality, always desired but never attained. He states:

[T]he aspiration to a rigorous reduction of one's possessions to a moderate size has been considered a desirable undertaking to this day, but it is hardly ever practiced, especially with regard to the equal distribution of moveable assets and cash. Whenever this was attempted with real estate, the result was for the most part unsuccessful. ${ }^{61}$

Bacon's position is in fact very pragmatic: whoever thinks that one can lend money without profit belongs ipso dicto to the realm of utopian dreamers:

It is a vanity to conceive, that there would be ordinary borrowing without profit; and it is impossible to conceive, the number of inconveniences that will ensue, if borrowing be cramped. Therefore, to speak of the abolishing of usury is idle. All states have ever had it, in one kind or rate, or other. So as that opinion must be sent to Utopia. ${ }^{62}$

\footnotetext{
York: Biblo \& Tannen, 1965), 182. Walter S. H. Lim, "Surety and Spiritual Commercialism in The Merchant of Venice," Studies in English Literature 50.2 (2010): 371.

59 Cf. Benjamin Ravid, "Money Lending in Seventeenth-Century Jewish Vernacular Apologetica," in Jewish Thought in the Seventeenth Century, eds. Isadore Twersky and Bernard Septimus (Cambridge: Harvard University Press, 1987): 262.

60 See above n. 58 for the reference.

61 Luzzatto, Discorso, 25v: 'Ma il volere con rigore ridure li haveri a segno di moderata proporzione, fu impresa sin ora desiderata, ma non giamai praticata, e massime l'uguaglianza de beni mobili, e danari contanti, e se fu alcuna volta attentata nelli beni stabili riuscì sempre con infelice successo' (English translation by Ariella Lang).

62 Bacon, The Works, vol. 14, 416. Cf. The English Renaissance: An Anthology of Sources and Documents, ed. Kate Aughterson (London: Routledge, 1998), 548; Robert Appelbaum, Literature and Utopian Politics in Seventeenth-Century England (Cambridge: Cambridge University Press, 2002), 4.
} 
Luzzatto also refers to Thomas More's Utopia as concretisation of the 'machinate repubbliche' ('ingenious republics') of Socrates and Plato, where the distribution of goods was the chief element of their political thought. ${ }^{63}$ Bacon sums up his opinion on the re-integration of usury, stating that it should be reserved for a small group under government control: For 'it is better to mitigate usury, by declaration, than to suffer it to rage, by connivance. ${ }^{64}$ In his response to some criticisms of money lending, made both by philosophers and statesmen, Luzzatto uses the same argument as advanced by Bacon, focussing on the stimulus generated by the moneylenders:

[...] usury is a sin constantly condemned, but in every time and place practiced. For two stimuli of our fragility, contribute to it: the necessity of those who need the money and therefore give the interest, and the avidity of the moneylender. When such a transgression was not committed by a Jew, there was perhaps no lack of others, who with greater extortion of the poor and needy would practice such a contemptible profession, reducing the number of usurers. And I do not say this to defend such actions, but merely to demonstrate that such enormity, like some others, is not an essential property of the Jews, as many presume to assert; rather it is an accidental result that comes from the strictness of the life and conditions of the time. ${ }^{65}$

The reader acquainted with sceptical strategies will have already recognised here the argument against an essential property of the Jews (that is, 'is not an essential property of the Jews;' also see Sextus' usage of 'by nature') and the recurrence of the strategy of infinite regress as factual relation used in political discourse: If agent $A^{1}$ does not do a practise $\mathrm{P}$, there will be an $\mathrm{A}^{2}$ which will do $\mathrm{P}$. The argumentation does not presuppose a direct causality between $\mathrm{A}^{1}$ viz. $\mathrm{A}^{\mathrm{n}}$ and $\mathrm{P}$, but it implies the experienced fact $\mathrm{P}$ which requited a non-essential but accidental relation to $\mathrm{P}$. The only experienced fact is $\mathrm{P}$, the agent $\mathrm{A}$ which/who produces $\mathrm{P}$ is only accidental and therefore theoretically infinite. The relation from $P$ to $A$ is not essential, therefore it leads to $A^{n}$.

63 Luzzatto, Discorso, 22r-v: 'La massa degli huomini mentre non fosse stata dalla prudente diligenza di legislatori, e formatori di governi civili, distinta in varii ordini, e differenti classi rassembrarebbe maggior diformità che l'antico, e decantato cahos all'imaginatione de poeti giamai rappresentasse. Socrate, e Platone, nelle loro machinate republiche posero tal distribuitione, come principale elemento delle loro politie, e l'istesso osservò il moderno inventore della Utopia, et il simile ancora eseguirono tutti li praticanti, come parimente Aristotile nel primo della Politica, ch’impiegò ogni suo spi|rito in riordinare, e corregere le divisioni fatte da quelli doi gran maestri dell'umanità.'

64 Bacon, On Usury, XLI.

65 Luzzatto, Discorso, 42r-v: '[...] usura, peccato continuamente dannato, ma in ogni tempo e loco essercitato, concorrendovi due stimoli maggiori, ch'habbia la nostra fragilità, la necessità del mutuario che contribuisce l'usura, e l'avidità insaziabile del mutuante, che la riceve, e quando non fusse commessa dall'hebreo tal transgressione, non vi mancarebbeno forsi altri, che con maggior estorsione dell'indigente, e bisogno, essercitassero tal prava professione, riducendosi a minor numero gl'usurarii' (English translation by Ariella Lang). 


\section{Moral Scepticism, or, Stoic Teaching in Sceptical Dress: The Charakteres}

Chapter 11 of the Discorso marks the beginning of its second part. Luzzatto begins by observing, with Socrates, that the human being is nothing but 'a multiplicity of different animals, wrapped and entangled within themselves. ${ }^{96}$ Luzzatto refers to letter CXIII by Seneca ad Lucilium in which he purposely mentions the stoic doctrine of the multiple or animal soul in human beings, because virtues can only be animal in nature: virtutes esse animalia. ${ }^{67}$ The statement virtutes esse animalia goes back, according to the Stoic fragments, probably to Chrysippus. ${ }^{68}$ Luzzatto wishes to find a philosophical connection to affirm that the human soul is a mixture. He indirectly cites

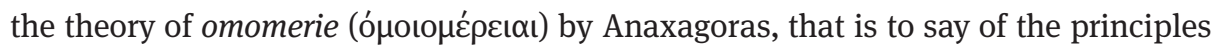
or roots of cosmological anthropological compositions forming a mixture in the body:

And if Anaxagoras, who denied that natural things are generated and because of this he introduced a certain confused mass composed of all things, and who judged that in all things there is another one annexed and attached, an opinion considered as absurd, had a similar thing proposed about human soul, may be his opinion would have been received with more applause by the learned, because if one considered attentively the movements of the soul, it would appear as a universal mixture of infinite things. ${ }^{69}$

Luzzatto's main objective is not so much contemplation about the composition of human personality, but rather discussion of the theme of virtue and vice in human beings. What follows is in fact a long passage on virtues and their obverse as individual characteristics in different moments and different locations:

66 Ibidem, 35v: '[Socrate] pronunziò non sapere se egli fosse un solo animale, overo una moltiplicità di diversi in se stessi anodati, ed invilupati, talmente trovava in se medesimo confuse le virtù, e li vizii, li eccessi, e le moderazioni.'

67 Seneca, ad Luciulium espistolae morales, liber XIX, CXIII,3: [2] 'Animum constat animal esse, cum ipse efficiat ut simus animalia, cum ab illo animalia nomen hoc traxerint; virtus autem nihil aliud est quam animus quodam modo se habens; ergo animal est. Deinde virtus agit aliquid; agi autem nihil sine impetu potest; si impetum habet, qui nulli est nisi animali, animal est. [3] "Si animal est" inquit "virtus, habet ipsa virtutem." Quidni habeat se ipsam? quomodo sapiens omnia per virtutem gerit, sic virtus per se. "Ergo" inquit "et omnes artes animalia sunt et omnia quae cogitamus quaeque mente conplectimur. Sequitur ut multa millia animalium habitent in his angustiis pectoris, et singuli multa simus animalia aut multa habeamus animalia." Quaeris quid adversus istud respondeatur? Unaquaeque ex istis res animal erit: multa animalia non erunt. Quare? dicam, si mihi accommodaveris subtilitatem et intentionem tuam. [4] Singula animalia singulas habere debent substantias; ista omnia unum animum habent; itaque singula esse possunt, multa esse non possunt.'

68 Stoicorum veterum fragmenta, vol. 3, ed. Hans F. von Arnim (Stuttgart: Teubner, 1964), 75; Stobaeus Ecl. 64,18 and 65,1; see also Thomas G. Rosenmeyer, Senecan Drama and Stoic Cosmology (Berkeley: University of California Press, 1989), 96.

69 Luzzatto, Discorso, 36r. 
The courage of living an adventurous life often derives from the fear one has of vulgar whispers and gossips, as on the contrary Fabius, cowardly in attacking Hannibal but intrepid scorner of the tongue of the plebeians, the greediness of prolonging life and enjoying its pleasures putting the weak but durable avidities before the vehement and short ones, makes us tempered and moderate: whereas Socrates following Plato who discovered in his Phaedo this great arcane called morality that the moderates, 'intemperantia quadam temperantes sint, e cosi timiditate forte sint,' and Solomon in Ecclesiastes c. 4 said, 'et contemplatus sum omnem laborem, et omnem rectitudinem operum, et ecce ipsa esse invidia hominis de socio suo,' as in Hebrew; that is to say that the vulgar virtues are envy, competition and emulation keeping men close to one another, confusing in the way virtues and vices.

[36v] Pleasure, the principal and most attractive object of our soul, is always mixed together with pain, its contrary, as Plato demonstrates in Philebus, hunger and thirst are the major condiments for out taste, tragic representations move us and produce in us indignation against tyrants, nevertheless we feel a certain hidden pleasurable itch and irritation, which amuses and

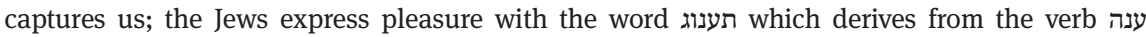
which also means affliction and therefore confirms the above mentioned mixture.

The impulsive agitation of rage was commended by Homer as full of pleasantness and sweetness, in the same way in the fervour of love jealousy gets generated and therefore hate, as Tacitus said about Mount Lebanon mirum dictu tantos inter ardores opacum fidumque niuibus. Alexander, famous for his victories not less than for the virtues of his soul, so compassionate toward Darius and his women, was afterwards so inhuman against Parmenion and Clitus, who had put the dominion of the world in his hands, and also so cruel with Callisthenes, his master. Julius Caesar, ferocious and inhuman in Pharsalia but clement with Marcellus and indulgent with Brutus, his assassin. Nero, a monster for all times, sometimes was displeased by the fact that he was able to write, especially when he had to sentence criminals to death, even though he did not hesitate in applying it against his own mother [37r] and against Seneca, his master; he was a friend of virtue and doctrine but he hated those characters in others, and for that the most humorous of the poets who ever existed, Lucan, lost his life. At the time of the cruel proscription ordered by the triumvirate, where faith, charity and gratitude were exiled from the most eminent and well composed spirits of the republic, because these virtues could not be found in fathers, children and sibling, they took refuge among the abjections of the serfs and the obscenity of the harlots; among many, one of them suffered the last torments in order not to reveal the names of her dishonest friends. Socrates in the height of his wisdom found ignorance, and was therefore judged by the very wise oracle. Little irritated meekness becomes untamed haughtiness, and this, with masterful dexterity, converts itself in meek and flexible pleasantness. ${ }^{70}$

The careful reader has probably recognised part of the catalogue of the second book of Aristotle's Rhetoric: pleasure-pain, rage-meekness, friendship-hate, fear-courage, shame-shamelessness, compassion-disdain, envy-emulation. This list has a particular purpose: to demonstrate the multifaceted dimensions of the human soul. In the words of our character:

The internal image of our soul is composed of a mosaic which apparently forms a single idea, but once it approaches, it shows how it is accompanied by various fragments and vile little and precious stones connected and committed together. In the same way, our soul is mostly com- 
posed by different and divergent pieces; in various occasions each one of them shows itself with a different appearance. Therefore, describing the nature and condition of a single man is very hard and difficult, and even more so is the will to refer his actions and ideas to a single norm. This explains why so many authors can be found [37v] who have written on the nature of horses, dogs and falcons, and who have devised with such an exactitude their customs and conditions, while very few have wanted to deal with men, and even so only in passing. The one who talked about them better was Theophrastus, Aristotle's disciple, who reserved the enterprise for the last years of his life as he was already eighty years old, and compiled a historical treatise about it with observations on the characters of the human soul; a fragment of his work made it all the way down to us, the rest was destroyed by the inclemency of times. ${ }^{71}$

Luzzatto refers here to Theophrastus of Eresos, author of Charakteres, a series of characterisations of the human soul. Angelo Ambrogini, nicknamed Poliziano, translated the first fifteen characters into Latin. These characters were published in Basel in 1532 by Andreas Cratander and did not feature Poliziano as the translator. ${ }^{72}$ They were published again, this time with Poliziano's name, in Paris in 1583 by Frédéric Morel. Already in 1552 an edition of these works by Aldo Manuzio, with eight more characters added, had appeared thanks to the efforts of Giovanni Battista Camozza. In 1599, a second edition, titled Caratteri, was published in Leiden, including five more characters (21-28). This edition was discovered by Isaac Casaubon and copied once more by Marquard Freher. In 1620, Ansaldo Cebà ${ }^{73}$ published an Italian version of the first fifteen characters, probably without taking into consideration Manuzio's edition, possibly because, as Romizi believes, he was too young to know of it. In any case, he does not utilise the 1552 edition. Cebà's book was, however, present in Venice, as the ancient catalogue of the Marciana Library reveals. This publication most likely circulated even in the Venetian Ghetto because at that time Cebà, a priest, had an epistolary love affair with a famous poet of Jewish origins, Sara Copio Sullam, who we have previously discussed. ${ }^{74}$

The Venetian Rabbi's objective is now evident: referring not only to Aristotelian rhetoric or to Theophrastus' composition, he underlines a very popular rhetorical device of that time: the use of typical characters of seventeenth-century theatre. ${ }^{75}$ This representation of the affects of the human soul, and of its different characters, was a sign of distinction in a century of comedies and tragedies performed and sung on the stage. It will be exactly the above mentioned Cebà who publishes a detailed commentary to accompany Theophrastus' text. Something which does not escape the attentive reader is that emphasising the theatrical character of human soul also means

71 Ibidem, 37r-v.

72 I refer the reader to my source for this paragraph, Andreas Cratander, I caratteri Morali di Teofrasto, ed. Augusto Romiti (Florence: Sansoni, 1899), which is the critical edition of the Greeek text with Italian translation and notes.

73 Ansaldo Cebà, I Charatteri morali di Theofrasto interpretati per Ansaldo Cebà, ed. Cardinale Federigo Borromeo (Genoa: Pavoni, 1620).

74 Cf. Giuseppe Veltri, Renaissance, 226-247.

75 Cf. Silvia Carandini, Teatro e spettacolo nel Seicento (Rome: Laterza, 1990). 
negating objective responsibility: everyone is an actor on the theatrum mundi stage, always playing at a passion/affection or its reverse.

\section{Conclusion: Reluctant and Nude Truth}

At the end of this section of which the intent was to illustrate only some aspects of the Discorso, I would like to conclude with a central concept of Luzzatto's apologia of Jewish life in Venice: the 'reluctant and nude truth.'

Just at the beginning of the small treatise, the Rabbi ventures to present an image of Judaism that goes beyond prejudices and atavistic hatred. It is specifically addressed to the 'cultori dell'invita verità.' Exactly what is meant by this expression, which was used in the dedication, is not clear at first sight. Earlier translators have preferred to consider it as a misprint and to amend the text to 'invicta verità' ('unconquerable truth'). There is, however, no need to change the wording of the text, which in translation sounds.

I dare to bring this work, neglected and stripped of ornate diction, to your noble attention, while indeed being aware that lovers of reluctant Truth appreciate simplicity. For [this reluctant truth] takes the greatest delight in [its] very nakedness. I do not claim [3v] undeserved favour, nor extorted applause from you, as I recognize how unworthy and unmerited it would be; but I plead for the most candid and honest judgment of the issues discussed. ${ }^{76}$

The concept of 'reluctant truth' fits very well into the system of Luzzatto's political. Lovers of the 'reluctant/unwilling' truth accept it, regardless of the form in which it may be propagated. In Luzzatto's own words:

Therefore, with a minimum of talent that divine majesty granted me, I proposed to compose a concise but truthful account of this nation's principal rites and most commonly shared opinions, which are not dissonant or discrepant from the universal ones. In writing this text, I tried with all of my powers (even though I am from the same nation) to abstain from any emotionality or passion that could make me deviate from the truth. Thus I hope to meet discreet readers, who, void of any anticipation or troubled judgment, are not about to follow the vulgar custom of only approving and favouring happy and adventurous individuals, and always damning those who are disheartened and afflicted. Rather, with upright judgment they will balance their opinions on the subject, which my imperfection dictated to me, and in saying this I will omit an extended reflection on the antiquity of this race, on its unmixed blood, which has existed for such a long period of time, on the tenacity of this nation's rites and belief, and on its inflexibility during times of oppressions. I will only add to my aforementioned proposal a discussion of some of the profits that the Jewish nation that lives in Venice brings to this illustrious city. With this, I do not intend to offer any ambitious apparatus of profits and gains; rather I only wish to demonstrate that this nation is anything but a useless member of the general population of this city. ${ }^{77}$

76 Luzzatto, Discorso, 3r-v. A similar parallel appears in Francis Bacon, The New Organon, 14: 'For a naked mind is the companion of innocence and simplicity, as once upon a time the naked body was.' 77 Luzzatto, Discorso, $5 \mathrm{r}-\mathrm{v}$. 
The author's commitment to his truth should not hide the fact that Luzzatto is not speaking of the Aristotelian principle of non-contradiction, but of the political perception of that condition. His intention is to provide as neutral a portrait of the Jews as possible, describing their presence in Venice and the (economic) advantages they bring. Although himself a member of the Jewish 'nation', a pars in causa, he will nevertheless maintain his impartiality. In return for his unbiased presentation of the argument, he expects his readers to form their opinion on the subject without prejudice.

The expression 'nudity of the truth' is very intriguing. The reader of Luzzatto was acquainted with the concept of nuda veritas since Horace, ${ }^{78}$ but also of its contradictory nature. For the nudity was, obviously, tantamount to purity and simplicity but also implied a lack of defences. The Florentine painter Sergio Botticelli recreated the Calumny of Apelles, a lost painting of the Greek painter Apelles, the story of which has been reported or perhaps invented by Lucian. ${ }^{79}$ A slander, a rival of Apelles, accused the painter of revolt in front of King Midas:

On the right sits a man with long ears almost of the Midas pattern, stretching out a hand to Slander, who is still some way off, but coming. About him are two females whom I take for Ignorance and Assumption. Slander, approaching from the left, is an extraordinarily beautiful woman, but with a heated, excitable air that suggests delusion and impulsiveness; in her left hand is a lighted torch, and with her right she is holding a youth by the hair; he holds up hands to heaven and calls the Gods to witness his innocence. Showing Slander the way is a man with piercing eyes, but pale, deformed, and shrunken as from long illness; one may easily guess him to be Envy. Two female attendants encourage Slander, acting as tire-women, and adding touches to her beauty; according to the cicerone, one of these is Malice, and the other Deceit. Following behind in mourning guise, black-robed and with torn hair, comes (I think he named her) Repentance. She looks tearfully behind her, awaiting shame-faced the approach of Truth. That was how Apelles translated his peril into paint. ${ }^{80}$

In the depiction of Botticelli, the Truth is naked, a nakedness which can have three possible meanings: 1) purity and simplicity, which causes or it is caused by innocence; 2) lack of defence; and 3) extreme difficulty in catching an adversary (e.g. in the Olympic games). While the first and the second possibilities are expressions of weakness and literary 'imbecility' (incapability of fighting and defending oneself),

78 Horace, Odes and Epodes, eds. Paul Shorey and Gordon J. Laing (Chicago: Benj. H. Sanborn \& Company, 1919), 1.24:

cui Pudor et Iustitiae soror

incorrupta Fides nudaque Veritas

quando ullum inveniet parem?

79 Cf. Rudolph Altrocchi, “The Calumny of Apelles in the Literature of the Quattrocento," Modern Language Association 36.3 (1921): 454-491.

80 The Works of Lucian of Samosata, vol. 4, eds. Henri W. Fowler and Francis G. Fowler (Oxford: The Clarendon Press, 1905), 2-3. 
the third one is almost the reverse, revealing the 'sceptic' attitude of a bodily description.

Back to the picture: a very similar 'translation' of a process of judgment into a piece of theatre has been presented by Luzzatto in his Socrate, where the theatrical figures of Defamation, Suspicion, Ignorance, Fame, and Custom (as ministers of Authority/Slander) appear. ${ }^{81}$ In another passage of the Socrate, he comes back to the comparison between truth and nudity. ${ }^{82}$ Here he is dealing with the consequences of his attitude to his enquiry 'concerning the cognition of the truth, convinced to suspend and withhold [my] assent.' His hesitation and perplexity lead him 'to consider whether it was a profitable decision to publicly discredit our alleged knowledge.' Disclosing the truth, he maintains, does not always fulfil our interest, like the nudity of our body, although 'the members were masterly constructed by the supreme Nature it often turns out to be indecent that the truth should appear to vulgar men without any ornament.'

The truth of cognition is like nudity, appreciated by lovers but also likely considered indecent by common people. The indirect reference is obviously to Genesis 3 and the creation of the feeling of shame in seeing nudity after the primordial sin. For Luzzatto, this indecency is a feeling of vulgar men, provoked by the nudity of the truth. This indecency can also prompt scepticism concerning the effectiveness of the decision to 'publicly discredit our alleged knowledge.' That is an extreme aspect of sceptical attitude: to be sceptical about one’s own scepticism.

81 Luzzatto, Socrate, 6-7: 'Yet, as soon as the traitor [i.e. Authority] had achieved so noble a rank and become impudent through the simple obedience and easy credulity of the stupid folk, it began conspiring against me. Felony went so far that it chased me out of my royal seat and brought and relegated me to a dark and lonely prison. Hence, as I have indeed lost my freedom, it was forbidden to have intercourse with my favourites and thus I became infertile and sterile [...] Indeed, it came so far only by means of sumptuous cloths, authoritative bearings, frowning, intimidating glances, furrowing its brows, concise and ambiguous words, brief and reluctant conversations, contemptuous and delusory manners, obstinate and Custom, both of them promoters of its acclaims and commendations.' Also ibidem, 65: 'retinenza di giuditio, tanto da miei adversarii calunniata, et al Vostro spettabile tribunale acramente hora accusata;' cf. ibidem 74, 77, and 299 (of the Italian original).

82 Ibidem, 256 (of the Italian original). 